\title{
A jūdō és a jiu-jitsu csatája - városi legenda vagy sporttörténeti tény?
}

\section{The Battle of Jūdō and Jiu-jitsu - An Urban Legend or a Historical Fact?}

\section{Papp Bendegúz}

Nemzeti Közszolgálati Egyetem, Rendészettudományi Doktori Iskola

\begin{abstract}
Absztrakt - Egy, a cselgáncsozók körében éló szóbeszéd szerint a sportág születésekor, az 1880-as években megmérkőztek egymással a jūdō és a jiu-jitsu legnagyobb harcmúvészei, ahol végül az elóbbiek győzedelmeskedtek. Mivel ez a történet jelenleg is a sportolók köztudatában él, fontos tisztázni az eset körülményeit, illetve hogy a legenda mennyiben felel meg a valóságnak. A kérdést a dokumentumelemzés módszerével jártuk körbe: felkerestük az összes releváns magyarországi könyvtárat és feldolgoztuk az ott fellelhető forrásokat. Ezen kívül felvettük a kapcsolatot három japán szervezettel, közülük a Tokiói Rendórkapitányság tudott információval szolgálni. A kapott eredmények alapján sikerült megállapítani, hogy valóban megtörtént a két iskola küzdelme, és a cselgáncsosok valóban több mérkózést nyertek. Ennek ellenére bizonyos fokig az összes forrás a jūdō szemszögéból íródott, akik érthető okokból eltúlozták a rendezvény jelentőségét. Feltételezhetően egy akkor nagy népszerúségnek örvendő közéleti eseményről van szó, amelyet a Kodokan-iskola felhasznált a jūdō terjesztésére mind Japánban, mind az egész világon.

Kulcsszavak: cselgáncs, technika, rendőrség, forráskritika
\end{abstract}

\begin{abstract}
According to a rumor among jūdō practitioners, at the birth of the sport in the 1880s, the greatest martial artists of jūdō and jiu-jitsu met each other, where the first ones have won. Since this story is still in the public consciousness of jūdōkas, it is important to clarify the circumstances of the case and its correspondence to reality. The issue was investigated by the method of document analysis: we visited all the relevant libraries in Hungary and analyzed the sources found there. In addition, three Japanese organizations were contacted, from which the Tokyo Police Department could provide some information. On the basis of the results, it was found that obviously the two schools organized a meeting, and the jūdō practitioners have actually won more matches than the jiu-jitsu ones. Nevertheless, to some extent, all of the found sources are more or less written from the point of view of the jūdō, so that they overacted the significance of the event. The challenge was supposed to be a public event of great popularity, and it was used by the Kodokan School to distribute the sport in Japan and all over the world.
\end{abstract}

Keywords: judo, technics, police, source criticism

\section{Bevezetés}

Jelen tanulmány az 1880-as években kialakult sportág, a jūdō1 (más néven cselgáncs) egyik fontos történelmi állomásával foglalkozik. A közhiedelem szerint az akkor frissen megalakított sportág és a nagy történelmi múlttal rendelkező jiu-jitsu megmérkőzött egymással, amely küzdelemből az előbbi került ki győztesként. Az sportolók ezt az esetet hallomásból ismerhetik az edzésekről, különféle

${ }^{1} J e l e n$ tanulmányban a japán szavak átírásánál a nemzetközileg elfogadott Hepburn-féle átírást használjuk, néhány más irásmóddal meghonosodott szó (pl.: Tokió) kivételével. A cselgáncs sportág japán nevét jūdō alakban használjuk. A jiu-jitsu sportág nevének számos átírása létezik (dzsiu-dzsicu, ju-jutsu, dzsú-dzsucu), itt egységesen a „jiu-jitsu” alakot alkalmazzuk. 
weboldalakról és egyéb publicisztikából. Ezekből három példát ismertetünk, az Ippon Judo Tatabánya Sportegyesület honlapjáról, a Judoinfo nevü népszerüsítő hírügynökség oldalról, és egy sporttankönyvből.

„1886-ban a Tókiói Városi Rendörség versenyt irt ki a Kodokan és a Totsuka Jiu-Jitsu iskola között azzal a céllal, hogy kiderüljön, melyik önvédelmi technikát érdemesebb tanitani, alkalmazni a rendörségeken. Kano2 tanitványai 13-szor nyertek, csupán kétszer nem tudtak gyözni. A verseny érdekessége, hogy két évig tartott. 1888- ban a Kodokan végérvényesen legyözte a Jiu-Jitsu iskolát. Jigoro Kano elsö tanitványai, Saigi Shiro és Yokoyama Sakujiro dobástechnikái nagymértékben hozzájárultak a sikerekhez." (Judo történet, é. n.)

"Az ifjú mester tagja volt annak a legendás Kodokan-csapatnak, amely a tokiói rendörség által megrendezett dzsu-dzsicu tornán gyözelmet aratva vezetö szerephez juttatta a Kodokan Judót a japán testnevelésben." (Gergely, é. n.)

"1886-ban a Tokioi Városi Rendörség versenyt irt ki a Kodokan iskola és a város egyik legnagyobb jujutsuiskolája (Totsuka) között, hogy eldöntsék, melyik önvédelmi rendszer hatékonyabb, s melyik harcmüvészet technikáit oktassák a továbbiakban a rendöröknek. A verseny két évig tartott, s a tizenöt küzdelemböl mindössze csak kettöt veszitett el Kano csapata." (Morvay-Sey, 2011)

Ebből a három idézetből is láthatjuk, hogy több ponton is különböznek az eseményleírások, így a sportágat művelők körében sem lehet egységes tudásanyag a jūdōtörténet e szegmensét illetően. A kérdés tisztázását azért tartjuk fontosnak, mert a sportág születésének egy jelentős momentumát taglalja, és ennek megértése hasznos adalékot jelent a sportág művelői számára. Jelen tanulmány a módszertani keret bemutatásával indul: részletesen leírjuk, hogy milyen csatornákon keresztül próbálkoztunk forrásbeszerzéssel, illetve hogy mi módon építettük fel a kutatás menetét. A második fö fejezet magával az eseménnyel foglalkozik, ütköztetjük a kapott adatokat, felderítjük a valós történelmi tényeket és megállapítjuk publicisztikában található esetleges tévedések okát is. A harmadik szakaszban az egész eseményt történelmi kontextusba helyezzük. Ez az elem azért fontos, mert véleményünk szerint a mérkőzés jelentőségét nem a rendőrkiképzés keretein belül, hanem a közéleti helyzet átvilágításával lehet csak megfelelően értelmezni.

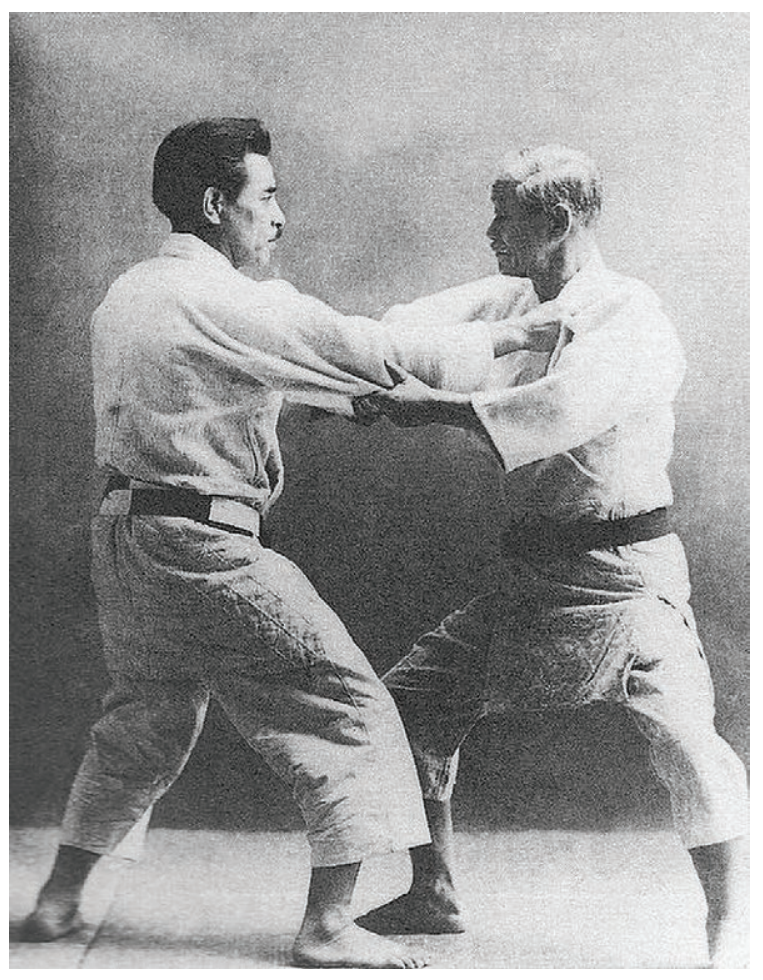

Kanó Dzsigoro és Mifune Kjūzō (Wikipedia)

\section{Tudományos probléma és módszertani keret}

A központi problémát az alábbi tisztázandó elemekre bontottuk fel: esemény dátuma (valóban 1886?), időtartama (egy nap vagy két év?), helyszíne (városi rendőrség vagy valamelyik edzőterem?), a küzdelmek kimenetele (végeredmény), illetve a jūdō esetleges későbbi rendészeti alkalmazása (városi vagy országos rendőrkiképzésnél, esetleg a nemzeti testnevelés-oktatásnál?). Abban az esetben, amikor több anyag is hasonló állítást közöl, igyekszünk megtalálni a hitelesebbet. A források elemzésénél így, amennyiben a szöveg nem hivatkozik más műre, megkeressük az adat feltételezhető eredetét, ezáltal megvizsgálva hitelességét.

A történelmi és közéleti kontextus vizsgálatánál dokumentumelemzést alkalmazunk. A források a puszta esetleíráson túl más gondolatokat is füznek a történtekhez: Kanō mester, a kortársak és más szerzők bőséges utalásokat tesznek az akkori aktuálpolitikai környezetre, és a verseny hatásait mindig így értelmezik. Ezért kritikai szemlélettel és a

\footnotetext{
${ }^{2}$ Kanō Jigorō, a Kodokan-intézet és vele együtt a sportág megalapitója.
} 
dedukció módszerével következtethetünk a jūdō és a jiu-jitsu közötti csata megrendezésének valós okairól és a kimenetel jelentőségéről is. A források beszerzését a Magyarországon elérhető könyvek, tanulmányok és egyéb publikációk megkeresésével kezdtük. A következő könyvtárakban gyüjtöttünk anyagot: Fővárosi Szabó Ervin Könyvtár, a Japán Alapítvány, a Nemzeti Közszolgálati Egyetem és a Testnevelési Egyetem könyvtára. Mivel az itthoni források megkeresése nem nevezhető teljes körü kutatásnak, felvettük a kapcsolatot azokkal a japán szervezetekkel, akik rendelkezhetnek némi információval az eseményről. Megkeresésünkre a Tokiói Rendőrség referense készségesen rendelkezésünkre bocsátott néhány japán nyelvű anyagrészletet, amelyek a rendőroktatás kora újkori történetével foglalkoztak. A globális jūdō központi intézetétől, a Kodokan Intézettől azt a választ kaptuk, hogy az intézet semmiféle forrással nem rendelkezik a mérkőzésről. Bár az állítás mögött inkább egy udvarias visszautasítást sejtünk, valószínűsíthető, hogy az intézet tényleg nagyon kevés információval rendelkezik az 1886-os versenyről. A Nemzetközi JiuJitsu Szövetségtől a kézirat lezárásáig nem érkezett válasz.

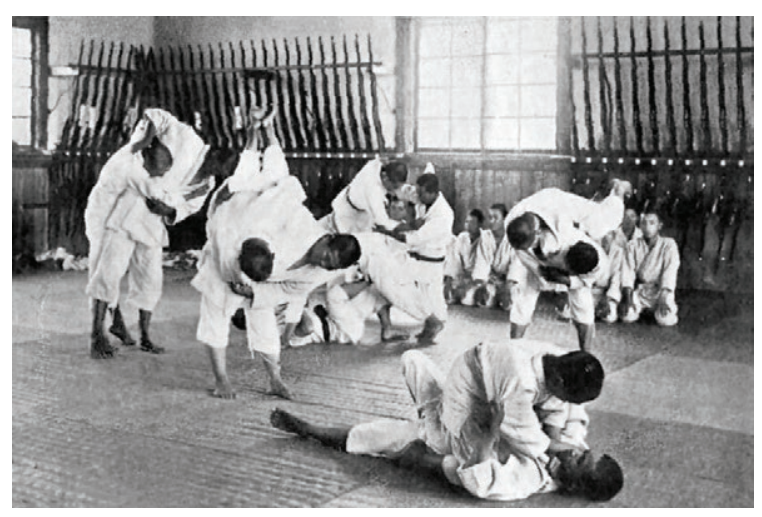

The Foundations of Japan (1922) (Wikipedia)

\section{Történelmi adatok}

Az adatelemzést azzal kezdtük, hogy sorra vettük a cselgánccsal foglalkozó anyagokat, és megkerestük a történeti fejezet(ek)nél, hogy említik-e a jūdō és a jiu-jitsu párharcát. Meglehetősen kevés magyar nyelvủ forrásanyag foglalkozik egyáltalán a sportággal, ezek közül kevesen említik az 1886os mérkőzést. (Galla, 1969; Galla és Nádori, 1964; Nagy, Ösze, Keserü és Vági, 2012; Sasaki, 1907; Szabó, 2013). Ezzel szemben - ahogy várható volt - az angol nyelvủ irodalom bőségesebbnek mondható, ám a következő kötetekben sem található információ az eseményröl. (Daigo és White, 2007; Inokuma és Satō, 2009; Kanō, 2002; Kano, 1947; Leggett, 1998; Mifune, 2004; Nakabayashi, Okamura, Nagao és Harper, 1966; Otaki és Draeger, 2011).

Takahashi (2005) könyve egy gyakorlati cselgáncskötet, célja az olvasó - aki feltehetően maga is jūdōka - látókörének kiszélesítése. Ennek megfelelően számos történelmi és filozófiai adalékot tartalmaz. A jūdō és a jiu-jitsu párharcát röviden említi meg: 1886-ra teszi, helyszínnek a Tokiói Városi Rendőrség jiu-jitsu találkozóját jelöli meg. Állítása szerint a 15 meccsből 13-at a cselgáncsosok nyertek meg, a maradék kettő pedig döntetlen lett. Szerinte ez a mérkőzés adta meg a lendületet a sportág elterjedéséhez az egész országban. Takahashi nem jelölte meg a forrást, ahonnan az adatokat vette, de mivel könyve egy ismeretterjesztő munkának számít, valószínűleg forrásként más hasonló ismeretterjesztő könyveket használt.

Galla Ferenc (1981) doktori dolgozatában a sportág oktatásmódszertanát dolgozza ki gyermekeknek. Munkájában a történelmi fejezetnél viszonylag hosszan kitér a kérdéses eseményre, évszám és végkimenetel tekintetében megegyezik Takahashival. Adalékként megjegyzi, hogy a győzelemhez valószínűleg nagyban hozzájárultak a Kanō által kidolgozott eséstechnikák, ennek köszönhetöen a cselgáncsosok esést követően rögtön folytatni tudták a mérkőzéseket, míg a jitsusok többnyire megsérültek esés közben. Galla az eséstechnikák szakértőjeként (Dobrotka és Galla, é. n.) utóbbi következtetésre valószínűleg egymaga jutott. Ezzel szemben a mérkőzés többi adatait nem tudjuk, honnan emelhette át, mivel Galla tanár úr - tudomásunk szerint - nem nagyon beszélt idegen nyelveket, és az általunk is megvizsgált korabeli magyar nyelvü szakirodalomban semmilyen utalást nem találtunk az eseményre. Valószínűsíthető, hogy valamelyik külföldi mester továbbképzésén hallhatta a történetet, azonban a leírtak így is túl részletesek ahhoz, hogy egy egyszer hallott elbeszélés alapján készültek volna.

Watson (2000) művében a jūdō atyja, Kanō Jigorō életrajzát taglalja, a mérkőzésről az előbbieknél sokkal részletesebb leírást adott, több oldalt is ennek szentelt: szerinte a verseny apropóját egy 1884-es ünnepség adta. Ekkor ugyanis átadták a Tenshin Shinyo jitsuiskola új küzdőtermét, és az ünnepségre ellátogatott néhány diák, akik a 
Kodokan Intézetben tanultak. A rendezvényen jelen volt Nakamura Hansuke jitsumester, aki a rendőrök harci kiképzésében vállalt aktív szerepet. A diákok és a mester között hangos szóváltás történt, és megállapodtak, hogy megküzdenek egymással ott, a helyszínen. Egy Tomita Tsunejiro nevủ diák egymás után háromszor is eldobta a mestert tomoe-nagéval, illetve egyszer hiza-gurumával, ami az elismert tanár tekintélyvesztéséhez vezetett. (Watson, 2000. 54-57)

Ekkortájt Japánban hagyományosan a jiu-jitsu valamelyik ágát oktatták mind a katonai, mind a rendőri kiképzésnél. Az említett ünnepség után közéleti kérdés lett, hogy vajon melyik a hatékonyabb: a jitsu vagy a jūdō, melyik oktatása lenne inkább célszerü. Ez a témakör különösen a Nemzeti Rendőrszövetségnél volt napirenden, az ő ötletük volt, hogy egy nagy mérkőzéssorozatot kellene szervezni, ahol sportáganként 15 személy küzdene meg egymással. Az eseményen olyanok vettek részt, akik a leginkább reprezentálták akkor a sportot: a jitsusok leginkább tanított iskolája a Totsuka volt, a csapatuk nagy része is innen került ki. Kanō azonnal felismerte a küzdelemben rejlő lehetőséget, elfogadta a kihívást. Négy, a mérkőzésen részt vevő tanítványa később nagyon híres mester lett: Tomita Tsunejiro, Yokoyama Sakujiro, Yamashita Yoshitsugu és Saigo Shiro, ők voltak a „Shitennó”, azaz az Ég Négy Ura. Maga a meccs 1886. június 11-én zajlott le, a tokiói Shiba park Yayoi-szentélyében. A Kodokan 12 meccset nyert, kettőt vesztett és volt egy döntetlenje is. A legnépszerűbb meccse Saigonak volt, aki a nálánál sokkalta nagyobb ellenfelét yama-arashival dobta meg. Ezek után a rendőrség, illetve a haditengerészet is belevette a jūdō-t a kiképzési programjába. (Watson, 2000. 59-61)

Meg kell említeni, hogy Watson szövege azért számít kifejezetten hitelesnek, mert Kanō életrajzát korabeli forrásokból és a mester feljegyzéseiből állította össze. Bár a küzdelmek forrását külön nem jelölte meg, valószínű, hogy itt is a mester visszaemlékezéseit vette alapul. Ezzel ellentétben a végkimenetel kérdése nem világos: Takahashi és Galla szerint 13 meccset nyert a Kodokan, míg Watson szerint csupán 12-őt. Ezen kívül a „döntetlen” fogalmát is nehéz értelmezni, a cselgáncs mai szabályai szerint ugyanis ilyen bírói döntés, amióta versenysport a jūdō, nem létezett és jelenleg sem létezik. Ezt az adatot leszámítva viszont egybehangzóak a források, Watson csupán mélyebben részletezi a körülményeket.

Meg kell említeni a bevezetésben is megjelölt források heterogenitását. Gergely Attila (é. n.) szerint az egész japán testnevelésben változás állt be a mérkőzés után. A tatabányai egyesület (Judo történet, é. n.) honlapja szerint a mérkőzés két évig tartott és 2001-es évszámmal Alex Butchert hivatkozza meg, azonban bibliográfia nélkül nem tudjuk, melyik műről van szó. Ezért valószínű, hogy egy puszta másolásról van szó egy másik internetes felületről, ahol azonban a cikk végén lehetett egy irodalomjegyzék. Morvay-Sey Kata (Morvay-Sey, 2011) nagyon hasonló szöveget jelentetett meg hivatkozás nélkül. Feltételezhető, hogy a forrás vagy a tatabányai egyesület oldala volt, vagy az egyesület által is használt közvetlen vagy közvetett forrás. Ez azért valószínűsíthető, mert a honlapon található „csupán kétszer nem tudtak gyözni” kifejezésből Morvaynál „csak kettöt veszitett el” lett, ami - mint tudjuk - nem fedi le a valóságot, egy félreértelmezés eredménye. Butcher (Butcher, Szabó és Reyneke, 2003; illetve Butcher, 2003) 2003-as (!) könyvében megtaláljuk a kérdéses szövegrészt a 11. oldalon, ami még egy félreértésre rávilágít. Butcher állítása szerint 1888-ra a jūdō véglegesen legyőzte a jiujitsut, már ami a népszerűségét illeti. Feltételezzük, hogy ez a kijelentés lett félreértelmezve, és így hihették azt a fenti idézetek szerzői, hogy két évig tartott a mérkőzéssorozat.

A következő tisztázandó pont a jūdō felvétele a japán rendőrség képzési programjába. A rendészeti szervek fizikai felkészítésében mindig is jelentős szerepet játszanak a sportok, küzdősport és harcművészetek (Ambrusz, Endrödi és Muhoray, 2016; Freyer, 2013, 2011; Kuti, 2008; Kuti és Papp, 2018; Teknös, Csepregi és Endrödi, 2014), így kiemelt kérdéskörről van szó. A tokiói rendőrség történetéről szóló kötet (Keishichō-shi 〈Dai 1〉 Meiji-hen, 1959) szerint a szervezet alapításától kezdve ${ }^{3}$ nagy hangsúlyt fektetett a fizikai felkészítésre, és ehhez nyilvánvalóan számos harcművészeti elemet is felhasznált. Mindazonáltal nem áll rendelkezésünkre olyan feljegyzés, ami információt adna a kiképzési és felkészítési program tartalmáról. Állítólag 1871 decemberében, azért, hogy a harcművészeti

${ }_{3}^{3}$ Bár Japánban korábban is léteztek rendészeti szervezetek, az európai mintára kialakitott rendörséget 1874-ben hozták létre. (Botsman, 2007) 
oktatást felügyeljék, megalapították a Japán Harcművészeti Egyesületet, azonban ezzel kapcsolatban is bizonytalanok a források, illetve semmit sem tudunk a későbbi szabályozásról sem. 1919-ben szabályozták meg a központilag a képzési anyagot, innentől írták elő kötelezően a harcművészeti oktatást a rendőrségnél.

Tehát azt nem tudhatjuk, hogy a tokiói, az egész japán rendőrségnél, a haditengerészetnél, vagy esetleg a közoktatásba bekerült volna a jūdō mint kötelező anyag. Viszont mivel ekkor nem beszélhetünk kiforrott, az egész országot behálózó, egységes rendészeti szervezetről, valószínűsíthető, hogy a cselgáncs maximum a fóvárosi szervnél kerülhetett alkalmazásra.

\section{A verseny történelmi kontextusban}

A források nagy része (Takahashi, 2005; Galla, 1981; Watson, 2000; Butcher, Szabó és Reyneke, 2003; Morvay-Sey, 2011; Gergely, é. n.; Judo történet, é. n.) a cselgáncs szemszögéből vizsgálja az eseményeket, illetve mindegyik megemlíti, hogy a rendezvénnyel el is dőlt, hogy a jūdō végérvényesen legyőzte a jiu-jitsut. Ez a megállapítás meglehetősen furcsa, ugyanis egy verseny alapján ilyen messzemenő következtetéseket nem lehet levonni, így fennáll a gyanú, hogy az akkori közéletet megvizsgálva árnyalhatjuk a sportról kialakított képünket. Kanō (Kanō, 2002. 19) visszaemlékezéseiben azt állítja, hogy az 1880-as évek végére már hanyatlófélben van a jiu-jitsu, ezért is volt szükség a megreformálására.

Watson (Watson, 2000. 50) szerint akkoriban Japánban volt egyfajta félelem is a harcmüvészekkel szemben: ők ugyanis nem voltak tisztelettudóak, több ízben inzultálták is a lakosságot. Kanō emiatt érezte fontosnak, hogy a testi képzés mellett szellemi „edzést” is előírjon tanítványainak (Sasaki, 1907). Ezért jogosan feltételezhetjük, hogy a híres győzelmet Kanō saját iskolájának legitimizálására használta fel. Akkoriban a mester mindent megtett azért, hogy mind Japánban, mind külföldön népszerűsítse módszerét, és ehhez a mérkőzés jó alapot szolgáltatott.

Megkeresésünkre a Kodokan Intézet azt válaszolta, hogy könyvtárukban nincs anyag a kérdéses mérkőzésről. Éppen ezért, bár valószínűleg az esemény a 19. század végén nagy visszhangnak örvendett, a forrásokban említett későbbi hatásait (japán testnevelés megreformálása, rendőrképzés átalakítása, a jiu-jitsu teljes legyőzése) fenntartásokkal kell fogadnunk. A Tokióban rendezett torna inkább egy közéleti eseménynek számított, mintsem egy tényleges szakmai diskurzus része lett volna, így messzemenő oktatáspolitikai következményei nem lehettek.

\section{Konklúzió}

Tanulmányunkban a jūdō és a jiu-jitsu közötti 1886-as mérkőzésnek jártunk utána. A kutatás keretei között feltérképeztük a Magyarországon elérhető angol, magyar és japán nyelvű szakirodalmat, a bennük található adatok alapján a következőkre jutottunk.

1886-ban ténylegesen lezajlott a verseny tokiói Shiba park Yayoi-szentélyében. A rendezvényt a tokiói rendőrség szervezte, és nagy népszerűségnek örvendett a lakosság körében. 15 küzdelemre került sor, ebből 12 vagy 13 menetet sikerült a Kodokan csapatnak nyernie. A cselgáncssport ezután gyors terjedésnek indult, valószínűsíthető, hogy a tokiói rendőrség is valamilyen módon bevette kiképzési programjába, de erről biztos adatunk nincsen. A jūdō képviselői ezek után úgy interpretálták, hogy győzedelmeskedtek a jiu-jitsu felett.

Érdekes jelenség, hogy a források - néhány különbséget, illetve a félreértelmezés miatt elkövetett tévedést leszámítva - hasonló adatokat közölnek. Bár akadnak pontatlanságok, ez annak tulajdonítható, hogy Watsont kivéve ezeknek a műveknek nem a történelmi hitelesség, hanem a puszta ismertetés volt a céljuk. Ha a történet pusztán szájhagyomány útján maradt volna fenn, rengeteg különféle változatban hallhattuk volna. Ezért valószínűsíthető, hogy létezett valaha egy eredeti forrás, ahonnan az esemény híre útra kelt, és innen eredeztetheto a „legenda”.

Ennek a dokumentumnak a felkutatására azonban jelen tanulmány keretei között nem vállalkozhatunk.

Bár az említett versenynek a jelenre, a jelenkori jūdōra nincs nagyon hatása, mindenképpen fontos, hogy tisztában legyünk a sportág gyökereivel. A cselgáncsszabályok - már amennyire a kezdetekkor szabályokról beszélhetünk, - azóta jelentősen megváltoztak, de a jūdō ennek a küzdelemnek köszönhette, hogy elterjedt Japán-szerte, majd elindulhatott világhódító útjára. 


\section{Irodalomjegyzék}

1. Ambrusz József, Endrődi István és Muhoray Árpád (2016): A Nemzeti Közszolgálati Egyetem Közös Közszolgálati Gyakorlatának a VIHAR 2016 összefoglalása, következtetései. Védelem Tudomány, 1 (4), 241-270.

2. Botsman, Dani (2007): Punishment and Power in the Making of Modern Japan. Princeton University Press, Oxford.

3. Butcher, Alex (2003): Judo: The Essential Guide to Mastering the Art. New Holland, London.

4. Butcher, Alex, Szabó Kisanna és Reyneke Ryno (2003): Judo: [útmutató a judo alapjainak elsajátításához. Totem, Budapest.

5. Daigo, Toshiro, és White, Françoise (2007): Kodokan Judo: Throwing Techniques. Kodansha International, Tokió.

6. Dobrotka Béla és Ferenc Galla (é. n.) Rendhagyó riport az Esések Iskolájáról. http://www. esesekiskolaja.hu/dr.-galla-ferenc-9-dan.html. (Utolsó letöltés: 2019. január 3.)

7. Freyer Tamás (2011): Testnevelési és Küzdősportok Tanszéke. In: Budaházi Árpád (szerk.): Jubileumi évkönyv : 40 éves a Rendörtiszti Föiskola, 1971-2011. Rendőrtiszti Főiskola, Budapest. 65-66.

8. Freyer Tamás (2013): Fizikai felkészítés a rendészeti felsőoktatásban. In: Kissné Ferencz Éva (szerk.): Sport, egészség, életmód, S. n., Budapest. 3 .

9. Galla Ferenc (1969): Cselgáncs (Judo) és önvédelem (Aikido). Sport Kiadó, Budapest.

10. Galla Ferenc (1981): Adalékok a cselgáncs oktatásának pedagógiai technológiájához, különös tekintettel a 6-14 éves korúak tanítására és tanulására. Ph.D. disszertáció, Testnevelési Föiskola, Budapest.

11. Galla Ferenc és Nádori Pál (1964): A cselgáncs kézikönyve. Sport Kiadó, Budapest.

12. Gergely Attila (é. n.): A négy nagymester (1. rész). Judoinfo. http://www.judoinfo.hu/ index.php/homepage/erdekessegek/7271a-negy-nagymester-1-resz. (Utolsó letöltés: 2019. január 3.)

13. Inokuma, Isao és Satō, Nobuyuki (2009): Best $J u d o$. Kodansha International, Tokió.

14. Judo történet. (Szerző és év nélkül) Ippon Judo Tatabánya SE. http://ipponjudo.gportal. hu/gindex.php?pg=15200429 (Utolsó letöltés: 2019. január 3.)
15. Kanō, Jigorō (2002): Kodokan Judo. Kodansha International, Tokió.

16. Kano, Risei (1947): What is Judo? Kōdōkan, Tokió.

17. Keishichō-shi 『Dai 1 \Meiji-hen. (1959; Szerző nélkül) Keishichō-shi-hen-san iinkai, Tokió.

18. Kuti Rajmund (2008): A tűzoltóképzés sajátosságai Ausztriában. Védelem Tudomány 15 (6), 30-31.

19. Kuti Rajmund és Papp Bendegúz (2018): Analysis of Decision-Making Skills during Disaster Management Operations. Hadmérnök 13 (1), 210-216.

20. Leggett, Trevor (1998): The spirit of Budo: old traditions for present-day life. Kegan Paul International, London.

21. Mifune, Kyūzō (2004): The Canon of Judo: Classic Teachings on Principles and Techniques. Kodansha International, Tokió.

22. Morvay-Sey Kata (2011): Küzdösportok, küzdőjátékok. Dialóg Campus, Budapest.

23. Nagy György, Ösze Attila, Keserü József és Vági Miklós (2012): Judo kyu vizsgák. Magyar Judo Szövetség, Budapest.

24. Nakabayashi, Sadaki, Okamura, Henry, Nagao, Hikaru és Harper, Paul V. (1966): Judo. Sterling, New York.

25. Otaki, Tadao és Draeger, Donn F. (2011): Judo Formal Techniques: A Complete Guide To Kodokan Randori No Kata. Tuttle Publishing, Vermont.

26. Sasaki Kichisaburo (1907): Djudo - Japán Dzsiu-dzsicu tökéletesitett módszere. Kiadó nélkül, Budapest.

27. Szabó Balázs (2013): A cselgáncs történeti alapjai: dzsúdzsucu a japán harcművészeti kutatásban. Kalokagathia 50/51 (1), 112-125.

28. Takahashi, Masao (2005; szerk.): Mastering Judo. Human Kinetics, Champaign, IL.

29. Teknős László, Csepregi Péter és Endrődi István (2014): Felsőoktatási intézmények önkéntes mentőszervezeteinek jelentősége, helye, szerepe a katasztrófavédelem rendszerében. Hadtudomány 24 (1), 155-168.

30. Watson, Brian N. (2000): The Father of Judo: A Biography of Jigoro Kano. Kodansha International, Tokió. 